\title{
Mobile Augmented Reality: An Alternative Way toward Museum Visitors' Experience
}

\author{
Mohd Hisyamuddin Kassim, Ahmad Rafi Eshaq, Charles Peter Woods
}

\begin{abstract}
The research focuses on visitors' experience via Mobile Augmented Reality (MAR) approach exhibition. Since the museum considered as a complex public institution, it required intellectual involvement from various disciplines in determining design decision at multilayer of design stages. It triggers the research to theorize the complex design development by considering "visitors' experience" as the backbone of the research. This notion is closely related to the fundamental of the museum context where the research attempts to unfold the factors that constitute them and how its related to each other. The aim is to formalize the factors that constitute the MAR approach exhibition toward visitors' experience. There are two objectives; to investigate the visitors' expectation, physical exhibition setting and MAR application that assists various visitors' activities; to validate the factors that constitute to the MAR approach exhibition toward visitors' experiences. The research applies mix-mode method which consists of a literature review, interviews and questionnaire to validate the finding. The reflection, the research highlights the "visitors' experience" as the primary consideration in bridging the gap between curators and designers. Thus, it promises an alternative approach for the museum in harmonizing the visitors' experience in the exhibition spaces.
\end{abstract}

Keywords: Museum Visitors, Mobile Augmented Reality Approach, Museum Physical Environment.

\section{INTRODUCTION}

In the 21st century, the museum has shifted into a complex public institution. It is due to the advancement of interactive technology as well as the social and cultural demand of its society. This notion known as "paradigm shift" where juxtaposes the traditional museum features. Through the "reinventing the museum tool," it shifts traditional museum from collective-centric, closed, rigid, stagnant and authoritarian to the visitor-centric, open, flexible, evolving and community-minded institution [1]. Thus, the museum has shifted into a market-oriented institution [2]. This type of museum is self-funded and generated their income. The museum starts to use the term "client" [3] and treat them to the next level of experience instead of visitors [4]. It triggers the visitor study research to relate the nature of the retail environment in the context of the museum environment.

As mobile devices became more powerful, multifunction and designed in a smaller size, it establishes a new wave of a

trend. People start to carry whenever they go [5]. Furthermore, it becomes "next big thing" when integrated with Augmented Reality (AR) application [6]. The museum acknowledged its potential and attempted to utilize this phenomenon in the exhibition design. Thus, it required intellectual disciplinaries from various fields [7] to ensure the exhibition approaches are not obsolete and sensitive to the current trend of visitors [8].

Although there are numerous researchers explore the MAR approaches exhibition, only a few focusing on the visitor experience [9]. Most of the museum deployed mobile exhibition approach without thorough consideration of visitors' expectation and physical exhibition setting which constitute visitors' experience. It remains questionable regarding the efficiency of MAR toward the overall of visitors' experiences in the exhibition spaces.

\section{MAR APPROACH TOWARD "VISITORS' EXPERIENCE"}

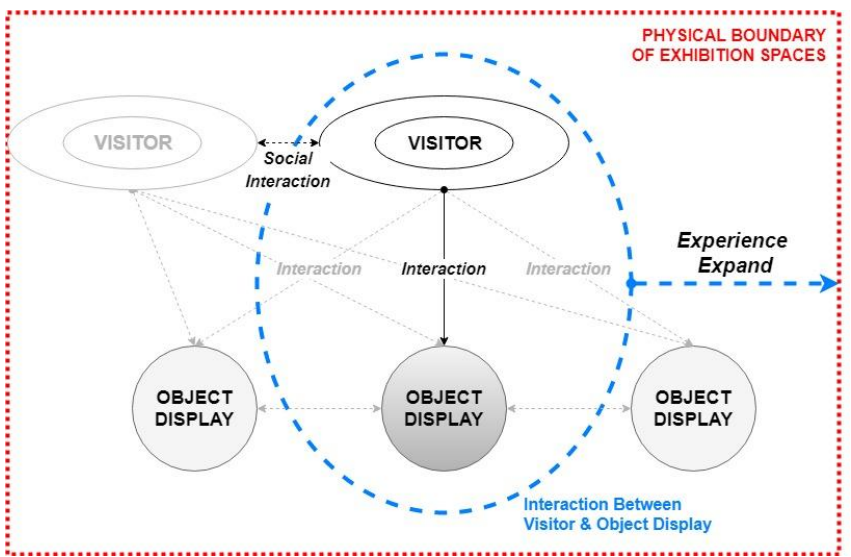

Fig.1. "Experience" via MAR Approach Exhibition

The "experience" is closely related to the multi-sensory understanding of museum environment in which visitors are interacting with [10]. It not about the number of the collections, but the way of its represent trigger the experience [11]. In fact, the "museological paradigm shift" highlighted the museum approach has shifted from being curatorial-centric and collection-centric to visitor-centric [12]. Thus, this notion shares authority in harmonizing visitors' experience.

As MAR capable of enhancing visitors' experience, the research thoroughly examined its potential. The research
Revised Version Manuscript Received on August 19, 2019.

MohdHisyamuddinKassim, Multimedia University Cyberjaya, Persiaran Multimedia, 63100 Cyberjaya, Selangor, Malaysia

Ahmad Rafi Eshaq, Multimedia University Cyberjaya, Persiaran Multimedia, 63100 Cyberjaya, Selangor, Malaysia

Charles Peter Woods, Multimedia University Cyberjaya, Persiaran Multimedia, 63100 Cyberjaya, Selangor, Malaysia 
highlights the fundamentals of museum context which consist of personal, social and physical context [13]. In this context, the research reveals the factors that constitute them and how its related to each other. In integrating MAR, the research adapts MAR guide for the museum visit [14]. This guide closely related to the behavior pattern within the spaces especially the visitors' movement. The aim is to understand the MAR properties and other enabling technologies that capable of assisting various visitors' activities.

In architectural topology, the exhibition considers as the core spaces. It serves as collecting and presenting spaces which closely related to appearance and atmosphere. In fact, its capable of establishing a museum statement and representation [15]. Thus, the researchers believed that the "experiences" not only covered interaction between object displays and visitors or other visitors but expended into the physical boundaries of the exhibition spaces through MAR approach. (see Fig.1)

\section{RESEARCH APPROACH}

The "experience" research associated with a complex and multidimensional [16]. It consists of physical, intellectual, social, emotion and spiritual aspect of visitors. To maintain consistency and clarity, the research focusing on the "museum interpretative" [17] on the MAR approach exhibition toward visitors' experience. The research thoroughly examines the fundamentals of the museum. It covers personal (the visitor as a unique individual in characteristics), social (the activities consist of a group of people) and physical (architectural component from macro to micro) [13]. Thus, the research adapts these fundamental in the context of visitors' experience via MAR approach exhibition. Thereis three research domain which is visitor study, exhibition design, and MAR application. It is closely related to design consideration which covers environmental variable and technology acceptance as well as shared design attributes which cover components configuration.

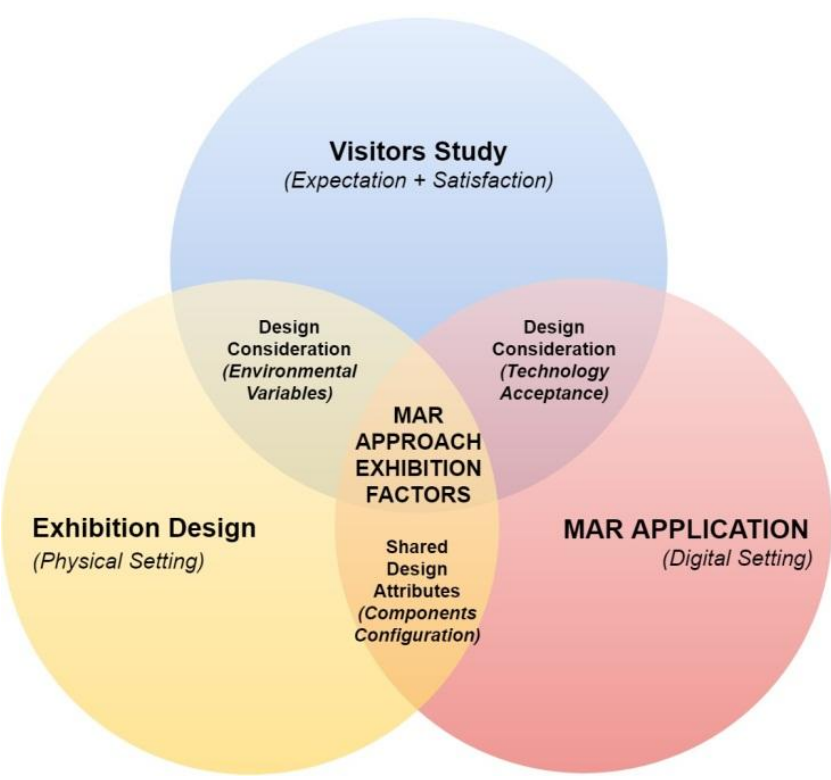

Fig.2. Research Domain related to MAR Approach Exhibition

\section{A. Visitors' Studies Theory and Expectation}

In defining visitors' experience, the research refers to the emergence of visitor study. The study covers visitors' profiles as museum end-users and their behavior which cannot be separated from emotions and equally, cognition works about the visitors' bodily movement [16]. It establishes the unique experiences based on the response in various ways based on their perception. Based on museum context, there are various type of visitors regarding the needs, expectations, and behaviors [3]. In fact, the visitors establish a unique need and expectation [18]. Thus, the research must understand the personal meaning of experience by investigating the wide-range of an affective and social range of visitors.

In characterizing the visitors' expectation, the research highlights visitors' profile. It consists of a pattern, behavior, attitude, and characteristic [19]. The research also emphasizes the nature of museum visit which based on a group of people for instances family and friend [20]. In the specific cases, there are also visitors with the disability, ethical background, educational needs and age group visit museum [20] as a part of the consideration.

In clarifying the visitors' attendance, the research examines the relationship between visitors' behavior and museum visiting inclination [21] for instances "confirmed non-goer" and "goer." It closely related to the behavior at a department store which known as the "experience economy." In this context, the "experience" as a commodity a good and services [22]. It classifies the behavior as "serious shoppers" "window shoppers" and "impulse shoppers." Thus, in the museum context, the visitors' attendance can be categorized into informal, repeat, regular, and particular interest as well as family and children which considered as a different category [20].

The research acknowledges "interest landscape" in observing visitors' behavior in the exhibition spaces [23]. It refers to "utility" and "spend" which establishesthe visitors" attention an interest. In this context, the attention influenced by environment and situational factors while the interest influenced by the visitors' characteristics. Thus, the research acknowledges the attention level which can be divided into three categories for instances capture, focus and engage [24].

The research also highlights the relationship between emotional and behavioral response. It is closely related to "input and output." where the emotion influenced by the various type of environmental stimuli [25]. The input refers to anything that can be perceived while the output refers to anything based on human performance. The emotional dimension can be categorized by arousal-nonarousal, pleasure-displeasure, dominance-submissiveness and approach or avoid. The result identified two main characters which are "approach behavior" and "avoidance behavior."

The museum activities encourage visitors to move from space to spaces and interact with other object display, physical environment as well as other visitors [26]. It is driven by interest and curiosity which contribute to the establishment of experience [27]. Thus, research refers to the 
experience model which consist of the dream, pragmatic and cognitive spaces [28]. In term of experience types, the research acknowledges the element that constitutes in the exhibition spaces which is object, cognitive, introspective and social experience [3]. Thus, the visitors' experience depends on museum content as well as visitors' characteristics.

\section{B. Environmental Psychology Theory and Variable}

The environmental psychology considered as emerged disciplines, for instance, architecture, interior design as well as social sciences [29]. This research shifted from laboratory research to the human behavior studies in the real setting. In a museum context, it refers to the impact on visitors' experiences in the exhibition spaces [30] which established various kind of behavior [25]. This environment consists of physical, social and cultural complexity. It offers a clue in determining the design decision which appropriates to visitors, for instance, visitors' attention and flows, affectiveresponse and social interaction level and quality. The failure in providing such an element might disturb the visitors' experience.

In examining the physical environment, the research refers to the environmental variable developed by Baker and Levy which consist of ambient, design and social [31]. It is closely related to the environmental dimension developed by Bitner which consist of an ambient condition, space/function and sign, symbols, and artifacts [32]. The findings indicate that it affects visitors cognitively, emotionally and physiologically.

The research found that both environment dimension highlights the difference in term of physical setting, some elements used the similar terms. In this context, the research refers to Wakefield and Blodgett dimension elements which are tangible and intangible elements [33]. The tangible element refers to the physical element that established the physical environment setting. Later, this dimension element extended and modified due to the design shape and experience [34].

\section{MAR Component, Requirement and Other Enabling} Technologies

AR technology always designed to enhance the emotional reaction for those who interact or engage with it [35]. It capable of generating complex and unforgettable experiences for visitors [36]. The museum started to adopt this technology through the MAR platform. Thus, MAR capable of extending the visitors' experience beyond the physicalboundaries of the exhibition wall and manage to invite the visitors to contribute to the meaning-making activities [37].

In implementing the MAR in the exhibition spaces, the research identifies the components and requirements associated with MAR. It consists of mobile computing platforms, displays screen, registration, wearable input and interaction technologies, wireless networking, and data storage and access. Furthermore, the research also highlights the requirements need to be considered in determining the computing platform. It consists of computer power required, form factor and the overall system ruggedness, power consumption, graphics and multimedia capabilities, expansion and interface ports availability, components upgradable, operating system and software development environments, technical support availability and prices [38]. In generating the virtual information in the real-time environment, the 3D graphics engine the play an important role in MAR platform. The MAR platform should consider graphics performances required, video and texture memory, graphics library support (OpenGL or Direct-X0, stereo driver availability, power consumption and price [38].

The research reveals the MAR features that commonly deployed in harmonizing the visitors' experience. The aim to identify the relevant features to assist visitors' exploration in the exhibition spaces. The features cover the preferred media, geolocalization, content storage and capacity, personalization, social context, continuity of usage, edutainment, delivery platform type and platform ownership. Regarding preferred media, there is a various form of digital information for instancesaudio, visual, multimedia and AR. In term of geolocalization, it supported by other enabling technology for instances declarative/explicit, Bluetooth, RFID, infrared and Wi-Fi. These enabling technologies integrated into MAR platform to support various visitors' activities in the museum exhibition spaces.

\section{RESULTS AND DISCUSSION}

In evaluating the finding, the research refers to the museum design research. This research deploys front-end and formative evaluation [39, 40]. The front-end evaluation covers pilot studies and exploratory literature review. The formative evaluation refers to museum experts' interviews and validation in formalizing the factors related to MAR approach exhibition.

Atthe front-end evaluation stage, the research categorized the factors that constitute the MAR approach exhibition toward visitors' experience. It consists of visitors' expectation, environmental variables, and MAR technology acceptance. In the context of visitors' expectation, the research emphasized on the satisfaction level.The assessment covers visitors' profile, behavior, emotion, and response. The result found that the components consist of enjoyment, meaningful experience, interest, curiosity, motivation, discovery, aesthetic, interaction and engagement, and satisfaction. As suggested by the museum experts, the research should consider leisure, surprise and social interaction and communication as a part of visitors' expectation components. However, the research found that these suggestions were not significant and fell under the highlighted components. Overall, the museum experts strongly agreed on the visitors' expectation components lead to visitors' satisfaction.

Inidentifying environmental variables, the research highlighted environmental psychology research. Thus, the researchassessed the visitors' impact on experiences. It establishes various visitors' pattern and behavior. The result found that the environmental variable consists of ambient (air quality, temperature, humidity, circulation, noise, scent, and cleanliness), space/function or design and sign, symbol, and artifact or design (functional, layout, comfort, signage, aesthetics, architecture, color, scale, material, texture/pattern, 
shape, style and accessories) and social (audience, number, appearance, behavior, and service personnel). Overall, the museum experts strongly agreed that environmental variables are interrelated to each other. These components are capable of harmonizing the visitors' experience during a museum visit via MAR application.

On MAR application, the research highlighted the MAR technology acceptance in evaluating the MAR approach exhibition. The components consist of ease of use, usefulness, surprise, new discovery, fascination, enjoyment and social interaction and communication. As suggested by the museum experts, the research should highlight the robustness and cognitive experience as the components in determining the MAR technology acceptance. Based on the analysis, the research found that these suggestions are not significant and fall under the highlighted components. (Refer to Table 1.)

Table 1. The Potential Factors for MAR Approach Exhibition

\begin{tabular}{|c|c|c|c|}
\hline Factors & $\begin{array}{l}\text { Visitors' } \\
\text { Expectation }\end{array}$ & $\begin{array}{l}\text { Environmental } \\
\text { Variables }\end{array}$ & \begin{tabular}{|l|} 
MAR \\
Technology \\
Acceptance
\end{tabular} \\
\hline Components & $\begin{array}{l}\text { Enjoyment } \\
\text { Meaningful } \\
\text { Experience } \\
\text { Interest } \\
\text { Curiosity } \\
\text { Motivation } \\
\text { New } \\
\text { Discovery } \\
\text { Aesthetic } \\
\text { Interaction } \\
\text { and } \\
\text { Engagement } \\
\text { Satisfaction }\end{array}$ & \begin{tabular}{|l|} 
Ambient \\
(Air Quality, \\
Temperature \\
Humidity, \\
Circulation, \\
Noise, Scent, and \\
Cleanliness) \\
Space/Function \\
or Design and \\
Sign, Symbol, \\
and Artifact or \\
Design \\
(Functional, \\
Layout, Comfort, \\
Signage, \\
Aesthetics, \\
Architecture, \\
Color, Scale, \\
Material, \\
Texture/Pattern, \\
Shape, Style and \\
Accessories) \\
Social \\
(Audience, \\
Number, \\
Appearance, \\
Behavior, and \\
Service \\
Personnel) \\
\end{tabular} & \begin{tabular}{|l|} 
Ease of Use \\
Usefulness \\
Surprise \\
New Discovery \\
Fascination \\
Enjoyment \\
Social \\
Interaction \& \\
Communication \\
\\
\end{tabular} \\
\hline
\end{tabular}

At the formative evaluation stage, the research conducted six museum expert interviews (n6) which consist of two curators, two interactive designers/developers, and two museum architects. The aim was to formalize the factors the constitute MAR approach exhibition. The selections are based on their involvement in museum exhibition design as well as related to the MAR approach exhibition. The assessment applied Likert Scale to evaluate the factors that constitute the MAR approach in exhibition spaces toward visitors' experience.
Table 2. The Visitors' Expectation on Museum Visit

\begin{tabular}{|c|c|c|c|c|c|c|}
\hline \multirow{2}{*}{$\begin{array}{l}\text { Visitors' } \\
\text { Expectation } \\
\text { Components }\end{array}$} & \multirow[b]{2}{*}{$\mathbf{t}$} & \multirow[b]{2}{*}{ df } & \multirow{2}{*}{$\begin{array}{l}\text { Sig. } \\
\text { (2-tailed) }\end{array}$} & \multirow{2}{*}{$\begin{array}{l}\text { Mean } \\
\text { Difference }\end{array}$} & \multicolumn{2}{|c|}{\begin{tabular}{|l|}
$95 \%$ \\
Confidence \\
Interval of \\
the \\
Difference \\
\end{tabular}} \\
\hline & & & & & Lower & Upper \\
\hline Enjoyment & 7.9 & 5 & 0.001 & 1.66667 & 1.1247 & 2.2086 \\
\hline $\begin{array}{l}\text { Meaningful } \\
\text { Experience }\end{array}$ & 6.7 & 5 & 0.001 & 1.50000 & 0.9252 & 2.0748 \\
\hline Interest & 7.9 & 5 & 0.001 & 1.66667 & 1.1247 & 2.2086 \\
\hline Curiosity & 7.9 & 5 & 0.001 & 1.66667 & 1.1247 & 2.2086 \\
\hline Motivation & 7.9 & 5 & 0.001 & 1.66667 & 1.1247 & 2.2086 \\
\hline New Discovery & 7.9 & 5 & 0.001 & 1.66667 & 1.1247 & 2.2086 \\
\hline Aesthetic & 6.7 & 5 & 0.001 & 1.50000 & 0.9252 & 2.0748 \\
\hline $\begin{array}{l}\text { Interaction and } \\
\text { Engagement }\end{array}$ & 7.9 & 5 & 0.001 & 1.66667 & 1.1247 & 2.2086 \\
\hline Satisfaction & 7.9 & 5 & 0.001 & 1.66667 & 1.1247 & 2.2086 \\
\hline
\end{tabular}

Table 1.describes the finding on visitors' expectation based on museum experts' validation. A single t-test was conducted to determine if a statistically significant different existed between visitors' expectation components from a sample used in the research and museum experts' validation. All components are statistically significant toward visitors' experiences on a museum visit. The museum experts agreed that the visitors' expectation components would lead to the visitors' satisfaction. However, the museum experts suggestedthat these components are interrelated to other factors for instances environmental variables and MAR technology acceptance.

Table 3. The Relationship between Visitors' Expectation and Environmental Variables and MAR Technology Acceptances

\begin{tabular}{|l|l|l|l|}
\hline Factors & & $\begin{array}{l}\text { MAR } \\
\text { Acceptances }\end{array}$ & $\begin{array}{l}\text { Environmental } \\
\text { Variables }\end{array}$ \\
\hline \multirow{2}{*}{$\begin{array}{l}\text { Visitor } \\
\text { Expectation }\end{array}$} & $\begin{array}{l}\text { Pearson } \\
\text { Correlation }\end{array}$ & $.826^{*}$ & -0.575 \\
\cline { 2 - 4 } & $\begin{array}{l}\text { Sig. } \\
(2-\text { tailed })\end{array}$ & 0.043 & 0.233 \\
\cline { 2 - 4 } & $\mathrm{N}$ & 6 & 6 \\
\hline
\end{tabular}

Table 2.describes the relationship between visitors' expectation and environmental variables and MAR acceptances. The result indicated a positive correlation between visitors' expectation and MAR acceptances, $r(5)=$ $.8, p=.04$. There was a statistically significant correlation between these two variables. The result indicated both factors statistically significance as factors that contribute to the visitors' experience. However, the result indicated negative correlation between visitor expectation and environmental variables, $r(5)=-0.6, p=.23$. There was no statistically significant correlation between these two variables. 
Table 4. The Relationship Between MAR Acceptances and Environmental Variables Components

\begin{tabular}{|l|l|l|l|l|}
\hline Factors & & Ambient & Spaces & Social \\
\hline $\begin{array}{l}\text { MAR } \\
\text { Acceptances }\end{array}$ & $\begin{array}{l}\text { Pearson } \\
\text { Correlation }\end{array}$ & -0.692 & -0.809 & 0.224 \\
\cline { 2 - 5 } & $\begin{array}{l}\text { Sig. } \\
\text { (2-tailed) }\end{array}$ & 0.127 & 0.051 & 0.670 \\
\cline { 2 - 5 } & $\mathrm{N}$ & 6 & 6 & 6 \\
\hline
\end{tabular}

Table 3.describes the relationship between MAR acceptances and environmental variable components for instances ambient, spaces and social. The result indicated a positive correlation between MAR acceptances and social components, $r(5)=.2, p=.7$. There was a statistically significant correlation between these two variables. However, the result indicated a negative correlation between MAR acceptances and ambient components $r(5)=-0.7, p=.1$ and spaces component $r(5)=-0.8, p=.05$. There was no statistically significant correlation between these three variables.

Table5. The Relationship between Social Components and Visitors' Expectation

\begin{tabular}{|l|c|c|c|}
\hline $\begin{array}{c}\text { Social } \\
\text { Components }\end{array}$ & $\begin{array}{c}\text { Pearson } \\
\text { Correlation }\end{array}$ & $\begin{array}{c}\text { Sig. } \\
\text { (2-tailed) }\end{array}$ & N \\
\hline Audience & -0.553 & 0.255 & 6 \\
\hline Number & -0.313 & 0.547 & 6 \\
\hline Apperance & 0.125 & 0.813 & 6 \\
\hline Behavior & -0.079 & 0.882 & 6 \\
\hline Service & 0.632 & 0.178 & 6 \\
\hline
\end{tabular}

Table 4.describes the relationship between social component (environmental variables) and visitors' expectation. There are positive correlations between social components and visitors' expectation, for instance, appearancer $(5)=.1, p=.8$ and service $r(5)=.6, p=.2$. Therewasstatistically significant correlations between these three variables. However, the result indicated a negative correlation between social components visitors' expectation, the for instances audiencer $(5)=-0.6 ., p=.3$, number $r(5)=$ $-0.3, p=.5$ and behavior $r(5)=.-0.08, p=.8$. There was no statistically significant correlation between social components (audience, number and behavior) and visitors' expectation.

\section{CONCLUSION}

The research attempts to formalize the factors that constitute the MAR approach exhibition. The research highlights "visitors' experience" as the backbone in bridging the gap between curator and designers (architect and software designer/developer). As MAR approach exhibition requires embodied interaction, the research believes that the experience not only limited between object displays and visitors but expanded into physical boundaries of museum spaces.

The research characterizes the visitors' expectation which later leads to visitors' satisfaction. The research suggests the components of enjoyment, meaningful experience, interest, curiosity, motivation, discovery, aesthetic, interaction and engagement, and satisfaction in determining visitor's satisfaction level. In embedding MAR approach in the physical exhibition spaces, the researchemphasizes on environmental psychology in identifying the environmental variables that influence visitors' experiences. The research suggests three main components which related to visitors' expectation; ambient (circulation), space/function or design (signage, aesthetic, material and accessories) and social (appearance and services). In determining the MAR approach exhibition assists visitors' experiences, the research emphasizes on mobile technology acceptances measure toward visitors' expectation. The research suggests the components of ease of use, usefulness, surprise, new discovery, fascination, enjoyment and social interaction and communication in determining the successfulness MAR approach exhibition.

In conclusion, these factors are interrelated to each other and involvedin every stage of design development. The research found that MAR approach exhibition capable of expending the experience to physical boundaries of the museum. By highlighting these factors, it promises a clue for curator and designer in developing a MAR approach exhibition toward visitors' experiences.

\section{REFERENCES}

1. Anderson, G., Reinventing the museum: Historical and contemporary perspectives on the paradigm shift. 2004: Rowman Altamira.

2. Golding, V., Learning at the museum frontiers: Identity, race, and power. 2016: Routledge.

3. McManus, P., Families in museums. Towards the museum of the future: New European perspectives, 1994: p. 81-97.

4. Saidon, H.J., S. Samsudin, and N.L.A. Rozak, Siapakahpelanggankita?:mengenaliprofildanselerapelangganMuzium \&GaleriTuankuFauziah, UniversitiSains Malaysia. 2010 Muzium\&GaleriTuankuFauziah, UniversitiSains Malaysia.

5. Craig, A.B., Understanding augmented reality: Concepts and applications. 2013: Newnes.

6. Jung, T.H., et al., Cross-cultural differences in adopting mobile augmented reality at cultural heritage tourism sites. International Journal of Contemporary Hospitality Management, 2018(just-accepted): p. 00-00.

7. McIntosh, J. and B. Marques, Designing for culturally-diverse communities. The role of collaborative, interdisciplinary design-led research. The Journal of Public Space, 2017. 2(3): p. 21-30.

8. Hwang, G.-J. and P.-H. Wu, Applications, impacts and trends of mobile technology-enhanced learning: a review of 2008-2012 publications in selected SSCI journals. International Journal of Mobile Learning and Organisation, 2014. 8(2): p. 83-95.

9. Kang, J., J. Jang, and C. Jeong, Understanding museum visitor satisfaction and revisit intentions through mobile guide system: moderating role of age in museum mobile guide adoption. Asia Pacific Journal of Tourism Research, 2018. 23(2): p. 95-108.

10. Naumova, A., " Touching" the Past: Investigating Lived Experiences of Heritage in Living History Museums. International Journal of the Inclusive Museum, 2015. 7.

11. Samis, P., The exploded museum. Digital technologies and the museum experience: Handheld guides and other media, 2008: p. 3-17.

12. Ellis, C., Hippies, Indians, and the Fight for Red Power. 2014, Utah State University Press.

13. Falk, J.H. and L.D. Dierking, The museum experience. 1992 Whalesback Books/Howells House.

14. Damala, A., et al. Bridging the gap between the digital and the physical: design and evaluation of a mobile augmented reality guide for the museum visit. in Proceedings of the 3rd international conference on Digital Interactive Media in Entertainment and Arts. 2008. ACM.

15. Hein, G.E. and M. Alexander, Museums: Places of learning. 1998 American Association of Museums, Education Committee. 
16. Hooper-Greenhill, E., Changing values in the art museum: Rethinking communication and learning. International Journal of Heritage Studies, 2000. 6(1): p. 9-31.

17. Hawkey, R., Learning with digital technologies in museums, science centres and galleries. 2004.

18. Bahrin, S.A.N.K., et al., Museum visitors' experiential factors and recommendation intention. 2017.

19. Stylianou-Lambert, T., Perceiving the art museum. Museum management and curatorship, 2009. 24(2): p. 139-158.

20. Black, G., The engaging museum: Developing museums for visitor involvement. 2005: Psychology Press.

21. Bennett, T., The birth of the museum: History, theory, politics. 2013: Routledge.

22. Pine, B.J. and J.H. Gilmore, Welcome to the experience economy. Harvard business review, 1998. 76: p. 97-105.

23. Bitgood, S., Attention and value: Keys to understanding museum visitors. 2016: Routledge.

24. Bitgood, S., Social Design in Museums: The Psychology of Visitor Studies: Collected Essays. Volume One. 2011: Museums.

25. Mehrabian, A., Public places and private spaces: The psychology of work, play, and living environments. 1980: Basic Books.

26. Hennes, T., Rethinking the visitor experience: Transforming obstacle into purpose. Curator: The Museum Journal, 2002. 45(2): p. 109-121.

27. Pallud, J., Impact of interactive technologies on stimulating learning experiences in a museum. Information \& Management, 2017. 54(4): p 465-478.

28. Goulding, C., The museum environment and the visitor experience. European Journal of marketing, 2000. 34(3/4): p. 261-278.

29. Holahan, C.J., Environmental psychology. 1982.

30. Smith, L., Theorizing museum and heritage visiting. The International Handbooks of Museum Studies, 2015.

31. Baker, J., M. Levy, and D. Grewal, An experimental approach to making retail store environmental decisions. Journal of retailing, 1992. 68(4): p. 445.

32. Bitner, M.J., Servicescapes: The impact of physical surroundings on customers and employees. the Journal of Marketing, 1992: p. 57-71.

33. Wakefield, K.L. and J.G. Blodgett, Customer response to intangible and tangible service factors. Psychology \& Marketing, 1999. 16(1): p. 51-68.

34. Rosenbaum, M.S. and C. Massiah, An expanded servicescape perspective. Journal of Service Management, 2011. 22(4): p. 471-490.

35. Fenu, C. and F. Pittarello, Svevo Tour: The Design and the Experimentation of an Augmented Reality Application for Engaging Visitors of a Literary Museum. International Journal of Human-Computer Studies, 2018.

36. Park, Y. and E. Bae, Creating Immersive Experiences in the Sokcho Museum. Advanced Science Letters, 2017. 23(10): p. 9886-9890.

37. Kuflik, T., et al., An integrative framework for extending the boundaries of the museum visit experience: linking the pre, during and post visit phases. Information Technology \& Tourism, 2015. 15(1): p. 17-47.

38. Arth, C., et al., The History of Mobile Augmented Reality Developments in Mobile AR over the last almost 50 years. 2015.

39. Adams, M., Museum Evaluation: Where Have We Been? What Has Changed? And Where Do We Need to Go Next?, in Professionalizing Practice. A Critical Look at Recent Practice in Museum Education. 2017, Routledge. p. 25-35.

40. Davidson, L., Visitor Studies: Toward a Culture of Reflective Practice and Critical Museology for the Visitor-Centered Museum. The International Handbooks of Museum Studies, 2015. 